\title{
Occurrence, speciation and transportation of heavy metals in 9 coastal rivers from watershed of Laizhou Bay, China
}

\author{
Li Xu ${ }^{\text {a, c }}$, Tieyu Wang ${ }^{b}$, Jihua Wang ${ }^{\text {a, c }}$, Anxiang Lu ${ }^{\text {a, c, * }}$ \\ a Beijing Research Center for Agricultural Standards and Testing, Beijing Academy of Agriculture \& Forestry Sciences, Beijing, 100095, China \\ b State Key Laboratory of Urban and Regional Ecology, Research Center for Eco-Environmental Sciences, Chinese Academy of Sciences, Beijing, 100085, China \\ c Beijing Municipal Key Laboratory of Agriculture Environment Monitoring, Beijing, 100097, China
}

\section{H I G H L I G H T S}

- High concentrations of $\mathrm{Cd}, \mathrm{Cu}$ and $\mathrm{Zn}$ in sediment and water were found.

- Among the studied elements, Cd was most strongly present in the exchangeable phase.

- The total mass fluxes of six metals in 9 coastal rivers were 869 tons per year.

- The upstream of Jie River has very high ecological risk for the water body.

\section{A R T I C L E I N F O}

\section{Article history:}

Received 24 November 2016

Received in revised form

4 January 2017

Accepted 6 January 2017

Available online 9 January 2017

Handling Editor: Shane Snyder

\section{Keywords:}

Heavy metals

Risk assessment

Speciation

Transportation

Jie river

\begin{abstract}
A B S T R A C T
The occurrence, speciation and transport of heavy metals in 9 coastal rivers from watershed of Laizhou Bay were investigated. The largest dissolved concentrations of $\mathrm{Cd}, \mathrm{Cu}$ and $\mathrm{Zn}$ in water were 6.26, 2755.00, $2076.00 \mu \mathrm{g} / \mathrm{L}$, respectively, much higher than several drinking water guidelines. The greatest concentrations of $\mathrm{Cu}, \mathrm{Zn}, \mathrm{Cr}, \mathrm{Ni}, \mathrm{Pb}$ and $\mathrm{Cd}$ in sediments were 1462, 1602, 196, 67.2, 63.5 and $1.41 \mathrm{mg} / \mathrm{kg}$, dw, respectively. Correlation and principal component analysis was also conducted to determine the extent between the concentrations of metals in water and sediment, as well as relevant parameters. Throughout the river stretch, most of $\mathrm{Cr} \mathrm{Zn}, \mathrm{Cr}$, Ni and $\mathrm{Pb}$ bound to residual fraction, however, $\mathrm{Cd}$ was preferentially bound to the exchangeable phase. Among the 9 rivers, Yellow river account for $72.5 \%, 67.5 \%, 55.4 \%, 59.4 \%$, $79.4 \%$ and $85.5 \%$ for $\mathrm{Cr}, \mathrm{Ni}, \mathrm{Cu}, \mathrm{Zn}$. $\mathrm{Cd}$ and $\mathrm{Pb}$, respectively. The combined potential ecological risk indexes were used to evaluate potential risks. The majority of sampling sites from watershed of Laizhou Bay have moderate ecological risk from metals. The government should pay more attention to the ecological risk of river ecosystem which flow to Laizhou Bay.
\end{abstract}

๑) 2017 Elsevier Ltd. All rights reserved.

\section{Introduction}

Contamination of rivers with toxic heavy metals due to natural processes such as atmospheric deposition, erosion and mineral weathering as well as anthropogenic activities such as urban, industry and agriculture are of great concern worldwide (Yang et al., 2013; Kadhum et al., 2015). Unlike organic pollutants which can be degraded to less harmful components by biological or chemical processes, metals in aqueous system are considered as not naturally decomposable and are often recycled via physiochemical and

\footnotetext{
* Corresponding author. Beijing Research Center for Agricultural Standards and Testing, Beijing Academy of Agriculture \& Forestry Sciences, Beijing, 100095, China. E-mail address: axlu2015@163.com (A. Lu).
}

biological processes, which continue to pose a risk of adverse effects on human health and aqueous ecosystem (Choi et al., 2012). As a result, extensive investigations about quantitative investigation of the trace metals in aquatic ecosystem were conducted (Gao and Chen, 2012; Huang et al., 2013; Zhuang and Gao, 2013).

The Laizhou Bay is one of the three Bays of Bohai Sea, which is an important area for fish's spawning, feeding and cultivation (Wang et al., 2014). The Laizhou Bay is also a part of the Bohai economic rim and Yellow River economic belt, one of the main parts of China's coastal economic belt (Xu et al., 2015). Due to intensive urbanization and industrialization, Laizhou Bay and nearby coastal areas have severe metal pollution problems. Large amounts of metals are carried into this Bay through either direct discharges or loads from rivers, such as the Yellow River and Xiaoqing River. For example, the Yellow River totally discharged $773 \mathrm{t}$ of metals in 
2008, and the Xiaoqing River totally discharged 1000 t of metals in 2011 (Luo et al., 2010). The accumulation of pollutants can be greater in semi-enclosed areas where the exchange of water with the open seas is limited (Wang et al., 2015). The Laizhou Bay has experienced dramatic reductions in species diversity and abundance, diseases in marine-cultured species, and habitat loss, which will ultimately destroy marine ecosystem structures and functions, and affect the health of human beings profoundly (Liu et al., 2015).

Metals contaminations of Laizhou Bay have been investigated over the past few years; however, almost all previous studies have focused on downstream and semi-enclosed sea areas (Liu et al., 2004; Hu et al., 2011; Zheng et al., 2015). The pollution characteristics of metals as well as the corresponding environmental risks within the coastal watersheds in upstream areas have received less attention. Secondly, the chemical speciation of metal in sediments along the main coastal rivers of Laizhou Bay is largely unknown. The sequential extraction protocols proposed by the Community Bureau of Reference (BCR) for metal speciation in river sediments were applied in this study (Farkas et al., 2007). Furthermore, the relationship between the concentrations of metals in water and sediment, as well as relevant physicochemical parameters is unclear. Beyond that, the riverine input of heavy metals to the Laizhou Bay is also unknown and need to be estimated.

Therefore, supplementary data on environmental quality in sediment and water of the entire region is urgently needed for a more comprehensive understanding. The objectives of this paper are: (a) to examine the contamination characteristics of metals in 9 rivers which flow into Laizhou Bay, (b) to study the distribution of speciation of metals in sediments from 9 coastal rivers, (c) to investigated the extent between the concentrations of metals in water and sediment, as well as relevant physicochemical parameters (d) to estimate riverine input of heavy metals to the Laizhou Bay, and (e) to investigate environmental risks associated with metal contents in sediment and water.

\section{Materials and methods}

\subsection{Samples collection and preparation}

Nine coastal rivers within latitude $36.58^{\circ}-37.76^{\circ} \mathrm{N}$ and longitude $117.42^{\circ}-122.26^{\circ} \mathrm{E}$, which flow into the Laizhou Bay, were selected. For each river, at least 2 sites were chose considering different volumes of discharge at distances of $20-30 \mathrm{~km}$ from the estuary. Mean annual precipitation in the study area is $740 \mathrm{~mm}$, mostly occurring from July to September, and mean annual air temperature is $13.6{ }^{\circ} \mathrm{C}$. Twenty six surface sediments and water samples were collected from 9 main rivers along the Laizhou Bay during September 2011 (Fig. 1).

Surface water samples were collected manually from the river. The samples were immediately filtered through acid-treated millipore filters $(0.45 \mu \mathrm{m}$ mesh) into pre-cleaned high density polyethylene (HDPE) containers in the field. The filtered samples were acidified to $\mathrm{pH}<2$ with ultra-purified $6 \mathrm{M} \mathrm{HNO}_{3}$ and then stored at $4{ }^{\circ} \mathrm{C}$ until analysis in the laboratory.

At each sampling point, approximately the top $5 \mathrm{~cm}$ of sediment was collected. All samples were sealed in clean polyethylene bags and put in a cooled box on site. Cooled samples were brought back to the lab and freeze-dried. And then, the sediment samples were crushed in an agate mortar, passed through a nylon 100-mesh sieve, and then stored at $4{ }^{\circ} \mathrm{C}$ in the dark before analysis of properties and concentrations of arsenic and metals. One part was crushed in an agate mortar to pass through a $2.0 \mathrm{~mm}$ mesh nylon

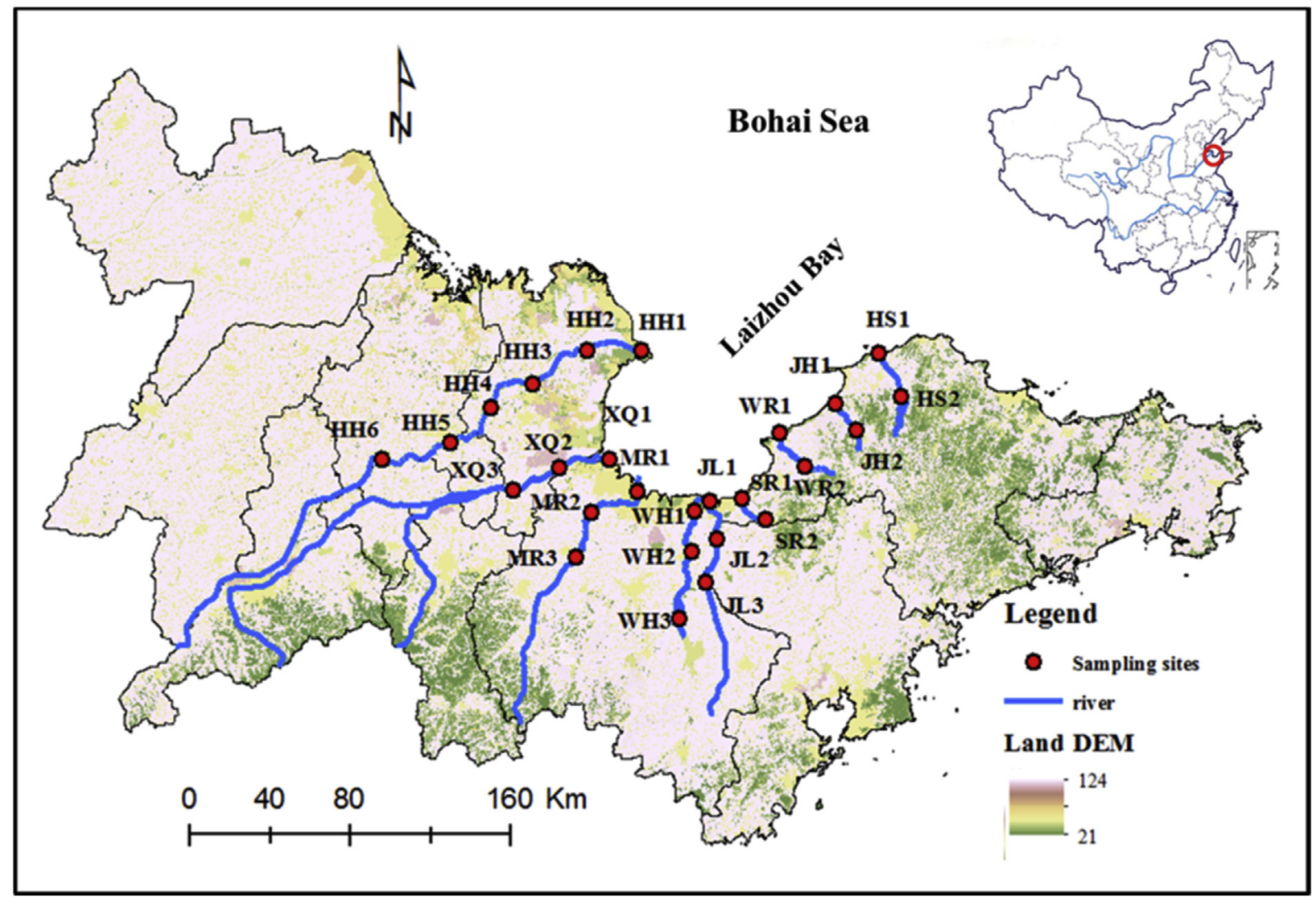

Fig. 1. Sampling sites from 9 coastal rivers around watershed of Laizhou Bay. 
Table 1

BCR sequential extraction scheme for heavy metal fractionation in sediments.

\begin{tabular}{|c|c|c|}
\hline Step & Phases & Procedure \\
\hline 1 & $\begin{array}{l}\text { Weak acid } \\
\text { soluble fraction }\end{array}$ & $0.11 \mathrm{M}$ HOAc, $20.0 \mathrm{~mL}$, room temperature, shake for $16 \mathrm{~h}$ \\
\hline 2 & $\begin{array}{l}\text { Reducible } \\
\text { fraction }\end{array}$ & $\begin{array}{l}0.50 \mathrm{M} \mathrm{NH}_{2} \mathrm{OH} \cdot \mathrm{HCl}\left(\mathrm{pH} 1.5 \text { with } \mathrm{HNO}_{3}\right), 20 \mathrm{ml} \text {, room } \\
\text { temperature, shake for } 16 \mathrm{~h}\end{array}$ \\
\hline 3 & $\begin{array}{l}\text { Oxidizable } \\
\text { fraction }\end{array}$ & $\begin{array}{l}30 \% \mathrm{H}_{2} \mathrm{O}_{2}, 10 \mathrm{ml}, 85^{\circ} \mathrm{C}, 1 \mathrm{~h} \text {, occasional shaking; add } 10 \mathrm{ml} \\
30 \% \mathrm{H}_{2} \mathrm{O}_{2}, 85^{\circ} \mathrm{C}, 1 \mathrm{~h} \text {, occasional shaking; add } 1 \mathrm{M} \mathrm{NH}_{4} \mathrm{Ac} \\
\left(\mathrm{pH} 1.5 \text { with } \mathrm{HNO}_{3}\right) 25 \mathrm{ml} \text {, shake for } 16 \mathrm{~h}\end{array}$ \\
\hline 4 & $\begin{array}{l}\text { Residual } \\
\text { fraction }\end{array}$ & digested with $\mathrm{HCl}-\mathrm{HNO}_{3}-\mathrm{HF}-\mathrm{HClO}_{4}$ \\
\hline
\end{tabular}

sieve for the determination of $\mathrm{pH}$, and another part was ground to pass through a nylon 100-mesh sieve for the determination of metals and total organic carbon (TOC).

\subsection{Analysis of metals}

Total concentrations of $\mathrm{Cu}, \mathrm{Zn}, \mathrm{Cd}, \mathrm{Cr}$, $\mathrm{Ni}$ and $\mathrm{Pb}$ in the water were analyzed using Inductively Coupled Plasma- Mass Spectrometry (Agilent 7500 ICP-MS) with an analytical precision better than $10 \%$. The detection limits were $0.02 \mathrm{mg} / \mathrm{kg}$ for $\mathrm{Cd}, 0.10 \mathrm{mg} / \mathrm{kg}$ for $\mathrm{Cr}$ and $\mathrm{Cu}$ and $0.50 \mathrm{mg} / \mathrm{kg}$ for $\mathrm{Ni}, \mathrm{Pb}$ and $\mathrm{Zn}$. Sediments were digested with a mixture of concentrated $\mathrm{HCl}, \mathrm{HNO}_{3}, \mathrm{HF}$ and $\mathrm{HClO}_{4}$ (Xu et al., 2013). Concentrations of metals, i.e., Cd, $\mathrm{Cu}, \mathrm{Ni}, \mathrm{Pb}, \mathrm{Cr}$ and $\mathrm{Zn}$ in the digestion solution were determined using ICP-MS. Standard reference materials, GBW-7 sediment, obtained from the Center of National Standard Reference material of China were analyzed as part of the quality assurance and quality control (QA) QC) procedures. The metal analytical concentrations for GBW-7 were within the range of the certified value and the replicate analysis of each batch of samples showed that the analytical precision was within $10 \%$ variability. The recovery rates of $\mathrm{Cu}, \mathrm{Zn}, \mathrm{Ni}$, $\mathrm{Pb}, \mathrm{Cr}$, and $\mathrm{Cd}$ and were $95-105 \%, 96-108 \%, 92-102 \%, 92-98 \%$, $101-105 \%$ and $98-103 \%$, respectively. Samples were carefully handled to avoid introduction or loss of trace elements during preparation and analysis. All materials used during analytical determinations were kept in Teflon or other metal-free containers. Sediment TOC was determined by titration with $\mathrm{FeSO}_{4}$ after digestion with a $\mathrm{K}_{2} \mathrm{Cr}_{2} \mathrm{O}_{7}-\mathrm{H}_{2} \mathrm{SO}_{4}$ solution (Zhu et al., 2014). Sediment $\mathrm{pH}$ was determined from a 1:2.5 water-sediment slurry using a pH meter (Wang et al., 2016).

The metals in all the sediments were fractionated according to the BCR sequential extraction as briefly described in Table 1 (Cuong and Obbard, 2006). The concentrations of the metals in different fractions and the resultant solutions of Step 4 were determined by ICP-MS. The standard reference material (BCR 701) was used to verify the accuracy of the sequential extraction method. The recovery rates for metals ranged from $92 \%$ (for $\mathrm{Zn}$ in the exchangeable phase) to $112 \%$ (for $\mathrm{Cr}$ in the residual fraction).

\subsection{Risk assessment and statistical methods}

The potential ecological risk index developed by Hakanson was adopted to evaluate the risk of heavy metals in sediments. This methodology was a very useful and comprehensive methodology which can be used to evaluate the combined pollution risk of an aquatic system through a toxic-response factor for a given substance (Hakanson, 1980). According to this methodology, the potential ecological risk index (RI) is defined as:

$\mathrm{RI}=\sum_{\mathrm{i}=1}^{\mathrm{n}}\left(\mathrm{T}_{\mathrm{i}} \times \frac{\mathrm{C}_{\mathrm{i}}}{\mathrm{C}_{\mathrm{o}}}\right)$

Where $\mathrm{Ti}$ is the toxic-response factor for a given substance (e.g. $\mathrm{Cd}=30, \mathrm{~Pb}=\mathrm{Cu}=\mathrm{Ni}=5, \mathrm{Cr}=2, \mathrm{Zn}=1) ; \mathrm{C}_{\mathrm{i}}$ represents metal content in the sediments; and $\mathrm{Co}$ is the background value of metals in the sediments (Xu et al., 2016). The average upper continental crust (UCC) values were adopted as the background value of metals in this study. The RI value is associated with a quantitative scale of pollution intensity, samples may be classified as following: $\mathrm{RI}<150$-low ecological risk for the waterbody; $150<\mathrm{RI}<300-$ moderate ecological risk for the waterbody; $300<\mathrm{RI}<600-$ considerable ecological risk for the water body; RI $>600$-very high ecological risk for the waterbody.

Statistical analyses were conducted using Microsoft Excel and SPSS 16.0 statistical software on a personal computer. ESRI ArcGIS 10.0 for Windows was used for the area digitization in order to display the spatial distribution of sampling sites around the watershed of Laizhou Bay. A spearman correlation analysis was conducted to identify the correlation coefficients among metals concentrations in water and sediment, as well as relevant parameters. PCA method with a VARIMAX rotation was adopted to identify possible source for metals in aquatic ecosystem.

\section{Results and discussion}

\subsection{Metals concentration in 9 coastal rivers of Laizhou Bay}

The descriptive statistics of dissolved heavy metals concentrations in water from 9 rivers around coastal area of Laizhou Bay were summarized in Table 2. For comparison, the average world background values were also shown. The results of the summary statistics (Table 2) indicate that dissolved metal concentrations in water were decreased in the order of $\mathrm{Cu}>\mathrm{Zn}>\mathrm{Ni}>\mathrm{Cr}>\mathrm{Pb}>\mathrm{Cd}$. The mean concentrations of the each metal in water were all higher than the corresponding average world background values. The $\mathrm{Cu}$ values had a coefficient of variation of $473 \%$, skew of 5.09 and kurtosis of 25.9, which were the largest of all the elements studied. This observation was the result of the heterogeneity of Cu contents, with a few locations having elevated concentrations. The greatest concentrations of $\mathrm{Cu}, \mathrm{Ni}, \mathrm{Pb}, \mathrm{Zn}$ and $\mathrm{Cd}$ were 2755, 59.0, 3.28, 2076 and $6.26 \mu \mathrm{g} / \mathrm{L}$, respectively, which all occurred at Jie River (JR). The

Table 2

Concentrations of dissolved metals in 9 rivers water from coastal area of Laizhou Bay (ug/L).

\begin{tabular}{|c|c|c|c|c|c|c|c|c|}
\hline & Mean & Median & Max & Min & $\mathrm{CV}^{\mathrm{a}}$ & Skew & Kurtosis & Background world average ${ }^{b}$ \\
\hline $\mathrm{Cu}$ & 114 & 3.75 & 2755 & 0.38 & 473 & 5.09 & 25.9 & 1.00 \\
\hline $\mathrm{Zn}$ & 113 & 12.3 & 2076 & 0.40 & 362 & 4.79 & 23.6 & 10.0 \\
\hline $\mathrm{Cr}$ & 3.52 & 1.88 & 16.2 & 0.66 & 118 & 2.17 & 3.96 & - \\
\hline $\mathrm{Ni}$ & 8.55 & 4.58 & 59.0 & 1.32 & 151 & 3.28 & 10.8 & 0.3 \\
\hline $\mathrm{Cd}$ & 0.49 & 0.12 & 6.26 & 0.08 & 273 & 3.87 & 15.2 & 0.02 \\
\hline $\mathrm{Pb}$ & 1.51 & 1.41 & 3.28 & 0.94 & 32.5 & 1.94 & 5.82 & 0.2 \\
\hline
\end{tabular}

a $\mathrm{CV}$ : Coefficient of Variation (\%).

b (Maris et al., 2000). 
Table 3

Metal concentrations in sediments from 9 coastal rivers $(\mathrm{mg} / \mathrm{kg})$.

\begin{tabular}{lllllllll}
\hline & Mean & Median & Max & Min & CV $^{\text {a }}$ & Skew & Kurtosis & UCC $^{\mathrm{b}}$ \\
\hline $\mathrm{Cu}$ & 90.9 & 17.9 & 1462 & 0.85 & 317 & 4.69 & 22.8 & 25.0 \\
$\mathrm{Zn}$ & 156 & 47.7 & 1602 & 8.10 & 205 & 4.02 & 17.8 & 71.0 \\
$\mathrm{Cr}$ & 54.2 & 45.6 & 196 & 0.45 & 83.6 & 1.61 & 2.96 & 35.0 \\
$\mathrm{Ni}$ & 23.1 & 21.3 & 67.2 & 1.92 & 57.6 & 1.33 & 3.63 & 20.0 \\
$\mathrm{Cd}$ & 0.19 & 0.13 & 1.41 & 0.07 & 142 & 4.06 & 17.3 & 0.10 \\
$\mathrm{~Pb}$ & 25.1 & 22.3 & 63.5 & 16.8 & 35.5 & 3.52 & 14.6 & 20.0 \\
$\mathrm{pH}$ & 7.83 & 7.89 & 9.16 & 6.49 & 7.54 & -0.13 & 0.22 & \\
$\mathrm{TOC}$ & 0.98 & 0.78 & 3.10 & 0.15 & 76.5 & 1.81 & 3.02 & \\
\hline
\end{tabular}

${ }^{\text {a }} \mathrm{CV}$ : Coefficient of Variation (\%).

b Average concentrations of the upper continental crust.

JR is located in the border of Zhaoyuan County, where has a long history of gold mining and smelting (Qian et al., 2010). As we known, the gold mining and smelting and subsequent leaching of tailings would cause a significant increase of metal concentrations in environmental (Osher et al., 2006; Edinger et al., 2008). So, the elevated dissolved metals concentration in water from JR has been shown to be most due to the gold mining and smelting.

Sediments act as both carriers and sink for heavy metals and therefore provide a record of catchment inputs into aquatic ecosystems. The concentrations of metals in surface sediments from 9 rivers around coastal area of Laizhou Bay were presented in Table 3. For comparison, the average upper continental crust (UCC) values were also shown. The results of the summary statistics (Table 3) indicate that metal concentrations in sediment were decreased in the order of $\mathrm{Zn}>\mathrm{Cu}>\mathrm{Cr}>\mathrm{Pb}>\mathrm{Ni}>\mathrm{Cd}$. The mean concentration of each metal from the 9 coastal rivers was higher than the corresponding UCC value. The $\mathrm{Cu}$ values had a coefficient of variation of
$317 \%$, skew of 4.69 and kurtosis of 22.8 , which were the largest of all the elements studied. The greatest concentrations of $\mathrm{Cu}, \mathrm{Zn}, \mathrm{Pb}$, and Cd were 1462, 1602, 63.5 and $1.41 \mathrm{mg} / \mathrm{kg}$, respectively, which all occurred at Jie River (JR). As mentioned above, some of the greatest metal concentrations were also observed in water at Jie River. The mining and smelting of gold ore at catchment of Jie River not only lead to elevated dissolved metals concentration in water but also result in the high concentration of $\mathrm{Cu}, \mathrm{Zn}, \mathrm{Cd}$ and $\mathrm{Pb}$ in sediments. Peak concentrations of $\mathrm{Cr}(196 \mathrm{mg} / \mathrm{kg})$ and $\mathrm{Ni}(67 \mathrm{mg} / \mathrm{kg})$ were observed from the Xiaoqing River (XQ3) and Wei River (WH3), respectively. And the industrial effluent and domestic sewage could be mainly responsible for the great concentrations of $\mathrm{Cr}$ and $\mathrm{Ni}$ in sediments from Xiaoqing River and Wei River (Huang et al., 2015). The TOC content in sediments ranged from 0.15 to $3.10 \%$ with a mean of $0.98 \%$. The $\mathrm{pH}$ value in sediments ranged from 6.49 to 9.16 with a mean of 7.83 .

\subsection{Speciation of metals in sediments}

The metals speciation in sediments is very important to understand because it affects metal mobility and availability (Akcay et al., 2003). In this study, the metals in 9 coastal rivers sediments were extracted into four fractions by using the BCR procedure. The chemical partitioning of trace metals in each sediment sample among the exchangeable, Fe/Mn oxide, organic/sulfides matter and residual fractions, is plotted in Fig. 2, Figs. S1-S5.

Throughout the river stretch, most of $\mathrm{Cr}$ bound to residual fraction, the proportion of residual fraction of $\mathrm{Cr}$ ranged from $40 \%$ to $94 \%$ with a mean of $83 \%$. The rest three phases decreased in the order of organic/sulfides (11\%), Fe/Mn oxide (4\%) and exchangeable

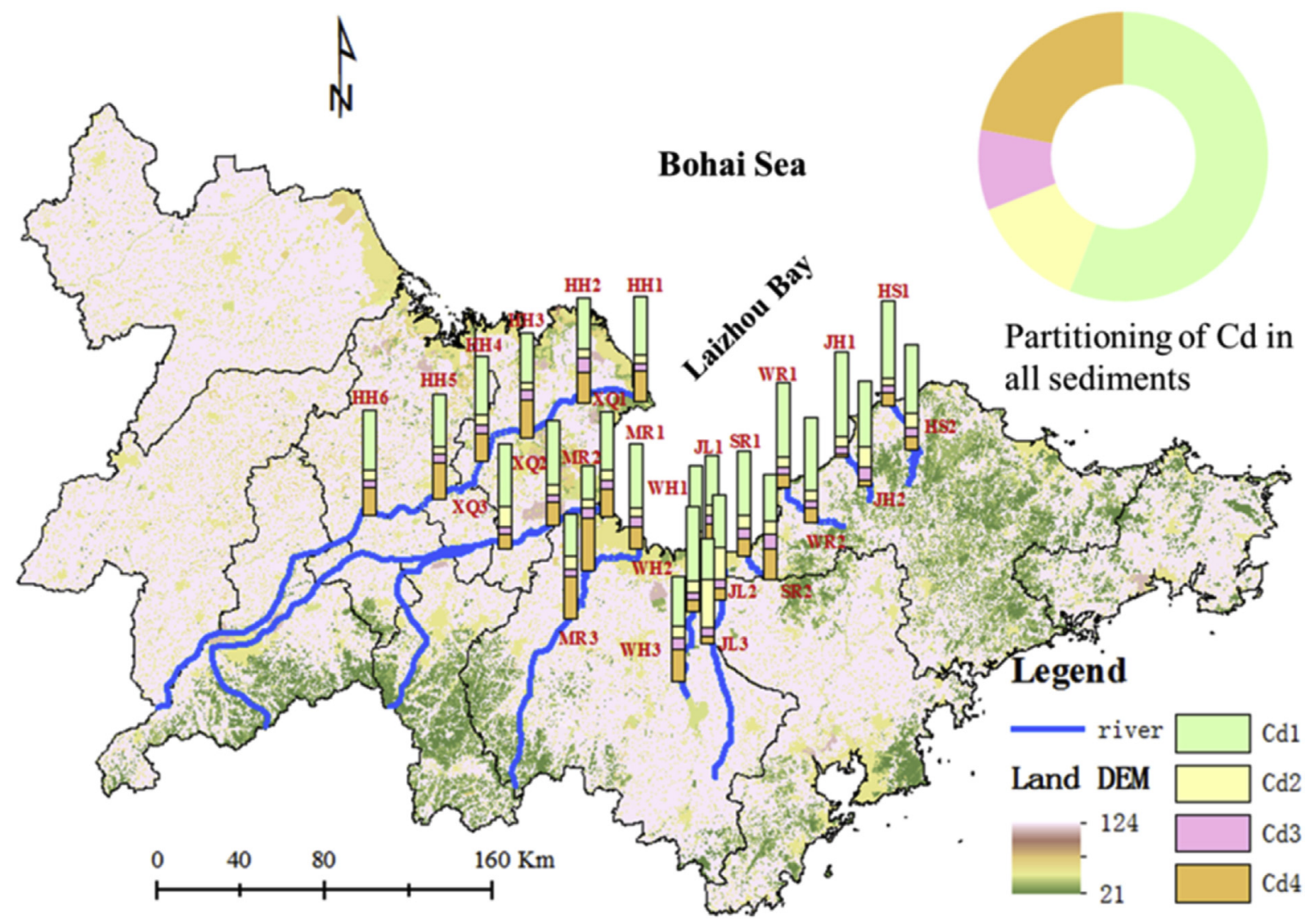

Fig. 2. The chemical partitioning of $\mathrm{Cd}$ in the sediment. 
Table 4

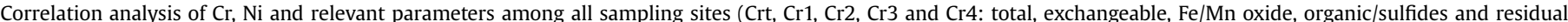

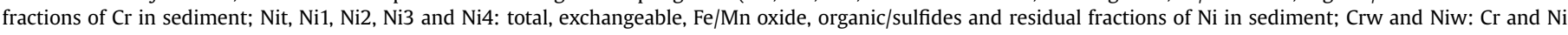
contents in water; pHs: sediment pH; pHw: water pH; DO: Dissolved oxygen; CD: Conductivity; ORP: oxidation reduction potential).

\begin{tabular}{|c|c|c|c|c|c|c|c|c|c|c|c|c|c|c|}
\hline & Crt & Cr1 & $\mathrm{Cr} 2$ & $\mathrm{Cr} 3$ & $\mathrm{Cr} 4$ & Crw & pHs & TOC & $\mathrm{pHw}$ & OD & $C D$ & Salinity & OPR & Turbidity \\
\hline Crt & 1.00 & $0.80^{\mathrm{a}}$ & $0.85^{\mathrm{a}}$ & $0.92^{\mathrm{a}}$ & $0.99^{\mathrm{a}}$ & 0.08 & $-0.47^{\mathrm{b}}$ & $0.47^{\mathrm{b}}$ & -0.29 & -0.35 & 0.38 & $0.42^{\mathrm{b}}$ & 0.06 & 0.25 \\
\hline $\mathrm{Cr} 1$ & & 1.00 & $0.88^{a}$ & $0.92^{\mathrm{a}}$ & $0.77^{a}$ & 0.33 & $-0.64^{\mathrm{a}}$ & $0.57^{a}$ & $-0.53^{\mathrm{a}}$ & $-0.50^{\mathrm{b}}$ & $0.68^{a}$ & $0.66^{\mathrm{a}}$ & -0.07 & 0.08 \\
\hline $\mathrm{Cr} 2$ & & & 1.00 & $0.92^{\mathrm{a}}$ & $0.80^{\mathrm{a}}$ & 0.26 & $-0.61^{\mathrm{a}}$ & $0.46^{\mathrm{b}}$ & -0.32 & -0.32 & $0.60^{\mathrm{a}}$ & $0.60^{\mathrm{a}}$ & -0.17 & 0.05 \\
\hline $\mathrm{Cr} 3$ & & & & 1.00 & $0.89^{a}$ & 0.19 & $-0.63^{\mathrm{a}}$ & $0.61^{a}$ & $-0.41^{\mathrm{b}}$ & 0.38 & $0.58^{a}$ & $0.58^{\mathrm{a}}$ & -0.05 & 0.07 \\
\hline $\mathrm{Cr} 4$ & & & & & 1.00 & 0.04 & $-0.44^{\mathrm{b}}$ & $0.42^{\mathrm{b}}$ & -0.28 & -0.34 & 0.36 & $0.40^{\mathrm{b}}$ & 0.07 & 0.26 \\
\hline \multirow[t]{2}{*}{ Crw } & & & & & & 1.00 & -0.10 & -0.24 & -0.26 & -0.29 & $0.69^{\mathrm{a}}$ & $0.72^{\mathrm{a}}$ & -0.01 & -0.11 \\
\hline & Nit & Ni1 & $\mathrm{Ni} 2$ & $\mathrm{Ni3}$ & $\mathrm{Ni} 4$ & Niw & $\mathrm{pHs}$ & TOC & $\mathrm{pHw}$ & OD & $C D$ & Salinity & OPR & Turbidity \\
\hline Nit & 1.00 & $0.76^{\mathrm{a}}$ & $0.71^{\mathrm{a}}$ & $0.86^{a}$ & $0.96^{\mathrm{a}}$ & 0.26 & -0.24 & $0.50^{\mathrm{b}}$ & -0.30 & -0.24 & -0.03 & 0.01 & 0.20 & 0.22 \\
\hline $\mathrm{Ni} 1$ & & 1.00 & $0.90^{\mathrm{a}}$ & $0.85^{\mathrm{a}}$ & $0.62^{\mathrm{a}}$ & $0.56^{\mathrm{a}}$ & $-0.59^{\mathrm{a}}$ & $0.67^{a}$ & $-0.46^{\mathrm{b}}$ & -0.32 & 0.23 & 0.20 & -0.31 & -0.10 \\
\hline $\mathrm{Ni} 2$ & & & 1.00 & $0.75^{\mathrm{a}}$ & $0.55^{\mathrm{a}}$ & 0.38 & $-0.58^{\mathrm{a}}$ & $0.51^{\mathrm{a}}$ & 0.31 & -0.19 & 0.14 & 0.11 & -0.23 & -0.07 \\
\hline $\mathrm{Ni3}$ & & & & 1.00 & $0.77^{\mathrm{a}}$ & $0.52^{\mathrm{a}}$ & $-0.40^{\mathrm{b}}$ & $0.50^{\mathrm{a}}$ & $-0.44^{\mathrm{b}}$ & -0.30 & 0.07 & 0.08 & -0.26 & 0.02 \\
\hline $\mathrm{Ni} 4$ & & & & & 1.00 & 0.16 & -0.13 & $0.42^{\mathrm{b}}$ & -0.24 & -0.26 & -0.05 & 0.01 & -0.17 & 0.32 \\
\hline Niw & & & & & & 1.00 & $-0.55^{\mathrm{a}}$ & 0.31 & $-0.61^{\mathrm{a}}$ & $-0.45^{\mathrm{b}}$ & $0.51^{\mathrm{a}}$ & $0.52^{\mathrm{a}}$ & -0.13 & -0.13 \\
\hline
\end{tabular}

Correlation is significant at the 0.01 level (2-tailed).

b Correlation is significant at the 0.05 level (2-tailed).

phase (1\%). Among the investigated elements, $\mathrm{Cr}$ was most strongly present in the residual phase. We can conclude that $\mathrm{Cr}$ in sediments from 9 rivers around Laizhou Bay is negligible pollutants, except for site XQ2, and mainly derived from natural processes such as weathering and soil formation. In the 9 investigated rivers, the operationally defined carrier phases of $\mathrm{Pb}$ were: residual phase $(73 \%)>$ Fe/Mn oxide $(20 \%)>$ organic/sulfides $(5 \%)>$ exchangeable (3\%). Although the average percentage of the exchangeable phase was not high (3\%), was the mean value of total content of $\mathrm{Pb}$ $(25.1 \mathrm{mg} / \mathrm{kg}$ ), the Fe/Mn oxide phase could be easily released from the sediment phase into the water with changing environmental conditions. As a type of environmental hormone, $\mathrm{Pb}$ can affect the procreation ability of a biological system (Yang et al., 2009).

Zn was mainly associated the residual phase (63\%), followed by the exchangeable phase (22\%), Fe/Mn oxide (9\%) and organic/sulfides (6\%). Cu preferentially bound to residual phase (57\%), while the exchangeable phase, Fe/Mn oxide (13\%) and organic/sulfides and accounted for $16 \%, 13 \%$ and $14 \%$, respectively. Ni remained mainly associated with residual phase (75\%). Throughout the river stretch, the operationally defined carrier phases of $\mathrm{Cd}$ were:

\section{Component Plot in Rotated Space}

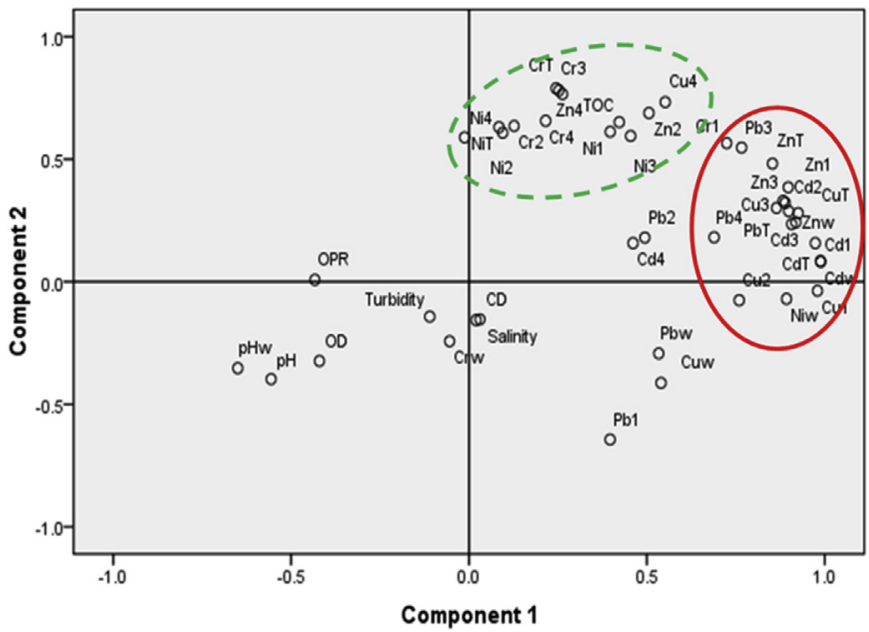

Fig. 3. Factors score distributions for metals concentrations in water, sediments and relevant parameters. exchangeable $(56 \%)>$ residual phase $(22 \%)>\mathrm{Fe} / \mathrm{Mn}$ oxide $(13 \%)>$ organic/sulfides (9\%). Among the investigated elements, $\mathrm{Cd}$ was most strongly present in the exchangeable phase, which indicated that the mobility and availability of cadmium in sediment from 9 coastal rivers were high (Yu et al., 2010). As a significant metal for environmental behavior (Chen et al., 2007), the potential Cd pollution in 9 coastal rivers should be pay lots of attention.

Throughout 9 coastal rivers, significant differences in heavy metal speciation could be observed. In the Jie River sediment, Cd, $\mathrm{Cu}$ and $\mathrm{Zn}$ were mainly associated with the exchangeable and organic/sulfides phase. In the Xiaoqing River, Zn showed significantly higher associations with $\mathrm{Fe} / \mathrm{Mn}$ oxide phase, the highest $\mathrm{Cr}$ which was associated with organic/sulfides phase was found. In the Jiaolai River and Jie River sediment, Pb showed significantly higher associations with $\mathrm{Fe} / \mathrm{Mn}$ oxide phase. While in the Yellow sediment, all of metals preferentially bound to residual phase, except for Cd.

\subsection{Correlation and principal component analysis}

A correlation analysis was conducted to determine the extent between the concentrations of metals in water and sediment, as well as relevant parameters (Table 4, Tables S3 and S4).

The total concentrations of each metal in sediments have a closed relationship with four fractions of corresponding metals, respectively. There are also significant correlations among different fraction of $\mathrm{Cr}, \mathrm{Ni}$ and $\mathrm{Cu}$ in sediments, which suggested that these three metals were mainly come from natural source. The dissolved $\mathrm{Ni}$ in water was significantly correlated with $\mathrm{Ni}$ of exchangeable phase and organic/sulfides in sediment. The dissolved $\mathrm{Cu}$ in water was significantly correlated with $\mathrm{Cu}$ of exchangeable phase in sediment. The dissolved $\mathrm{Zn}$ in water was significantly correlated with Zn of exchangeable phase, Fe/Mn oxide and organic/sulfides in sediment. The dissolved $\mathrm{Cd}$ in water was significantly correlated with $\mathrm{Cd}$ of organic/sulfides in sediment. The salinity values were significantly correlated or less correlated $(\mathrm{P}<0.05)$ the total concentrations and all fractions of $\mathrm{Cr}$ in sediments, and the salinity values were also less correlated $(\mathrm{P}<0.05)$ with dissolved $\mathrm{Cr}$ in water. This result indicated that the salinity play an important role to determine environmental behavior of $\mathrm{Cr}$ in aquatic ecosystem in studied area. The $\mathrm{pH}$ values in sediments were significantly negatively correlated $(\mathrm{P}<0.01)$ or less negatively correlated $(\mathrm{P}<0.05)$ total concentrations and all fractions of $\mathrm{Cr}$ and $\mathrm{Cu}$ in sediments. TOC in sediments were negatively correlated $(\mathrm{P}<0.01)$ or less correlated 
Table 5

Fluxes of dissolved metals in 9 rivers around the Laizhou Bay and in rivers in other regions (t/year).

\begin{tabular}{|c|c|c|c|c|c|c|c|}
\hline Rivers & $\mathrm{Cr}$ & $\mathrm{Ni}$ & $\mathrm{Cu}$ & $\mathrm{Zn}$ & $\mathrm{Cd}$ & $\mathrm{Pb}$ & Reference \\
\hline Yellow river & 49.1 & 87.7 & 102 & 246 & 3.98 & 58.0 & This study \\
\hline Xiaoqing river & 4.78 & 14.6 & 5.52 & 30.1 & 0.23 & 2.59 & This study \\
\hline Mi river & 0.89 & 2.30 & 1.35 & 5.19 & 0.05 & 0.70 & This study \\
\hline Wei river & 9.39 & 17.6 & 16.7 & 60.7 & 0.47 & 5.27 & This study \\
\hline Jiaolai river & 1.48 & 4.01 & 3.02 & 21.1 & 0.06 & 0.65 & This study \\
\hline Sha river & 1.00 & 0.97 & 1.83 & 3.82 & 0.03 & 0.35 & This study \\
\hline Wang river & 0.27 & 0.11 & 0.37 & 0.25 & 0.00 & 0.04 & This study \\
\hline Jie river & 0.06 & 1.86 & 52.4 & 46.2 & 0.18 & 0.10 & This study \\
\hline Huangshui river & 0.74 & 0.42 & 0.87 & 0.52 & 0.01 & 0.10 & This study \\
\hline Severnaya Dvina river (Russia) & 68.3 & 502 & 724 & 1823 & 3.14 & 37.5 & (Pokrovsky et al., 2010) \\
\hline St. Lawrence river (North America) & & 780 & 1200 & 4500 & 58 & & (Yeats and Bewers, 1982) \\
\hline Tinto river (Spain) & & 2.2 & 469 & 863 & 3.9 & 14.8 & (Olias et al., 2006) \\
\hline Odiel river (Spain) & & 33.9 & 1252 & 2612 & 7.1 & 11.8 & (Olias et al., 2006) \\
\hline Pearl river (China) & & & 1.85 & & 15.4 & 17.9 & (Ye, 2001) \\
\hline Min river (China) & & & 44.0 & & 1.9 & 16.0 & (Lin et al., 1989) \\
\hline
\end{tabular}

$(\mathrm{P}<0.05)$ the total concentrations of $\mathrm{Cr}, \mathrm{Ni}, \mathrm{Cu}$ and $\mathrm{Zn}$ in sediment, as well as all four fractions of $\mathrm{Cr}, \mathrm{Ni}, \mathrm{Cu}$ and $\mathrm{Zn}$ in sediment. The rest parameters influence metals concentrations in sediments and water more or less.

In multivariate statistical analysis, PCA can be used to identify the sources of metal contamination (Li et al., 2013). For PCA analysis, the factor loadings with a VARIMAX rotation as well as $\mathrm{cu}-$ mulative percentage of variance are used. Factors score distributions for metals concentrations in water, sediments and relevant parameters were shown in Fig. 3. According to metal concentration and chemical partitioning of metal, the total concentration of metal and the different speciation of metal in green ellipse are mainly come from natural source; the total concentration of metal and the different speciation of metal in red ellipse are mainly come from anthropogenic source.

\subsection{Riverine input of heavy metals to the Laizhou Bay}

Mass flux will provide information on the environmental inventory of heavy metals. The mass flux was calculated based on instantaneous concentrations of dissolved heavy metals multiplied by the average annual water discharge data to give rough yet valuable approximation. The estimated mass fluxes of dissolved metals in 9 rivers were shown in Table 5. The total mass fluxes of six dissolved metals in 9 coastal rivers were 869 tons per year. The results of the summary statistics (Table 3 ) indicate that the mass fluxes of six dissolved metals were decreased in the order of $\mathrm{Zn}>\mathrm{Cu}>\mathrm{Ni}>\mathrm{Pb}>\mathrm{Cr}>\mathrm{Cd}$. Among the 9 rivers, Yellow river account for $72.5 \%, 67.5 \%, 55.4 \%, 59.4 \%, 79.4 \%$ and $85.5 \%$ for $\mathrm{Cr}, \mathrm{Ni}, \mathrm{Cu}$, $\mathrm{Zn}$. Cd and $\mathrm{Pb}$, respectively. The primary reason for this phenomenon was the high average annual water discharge of Yellow River

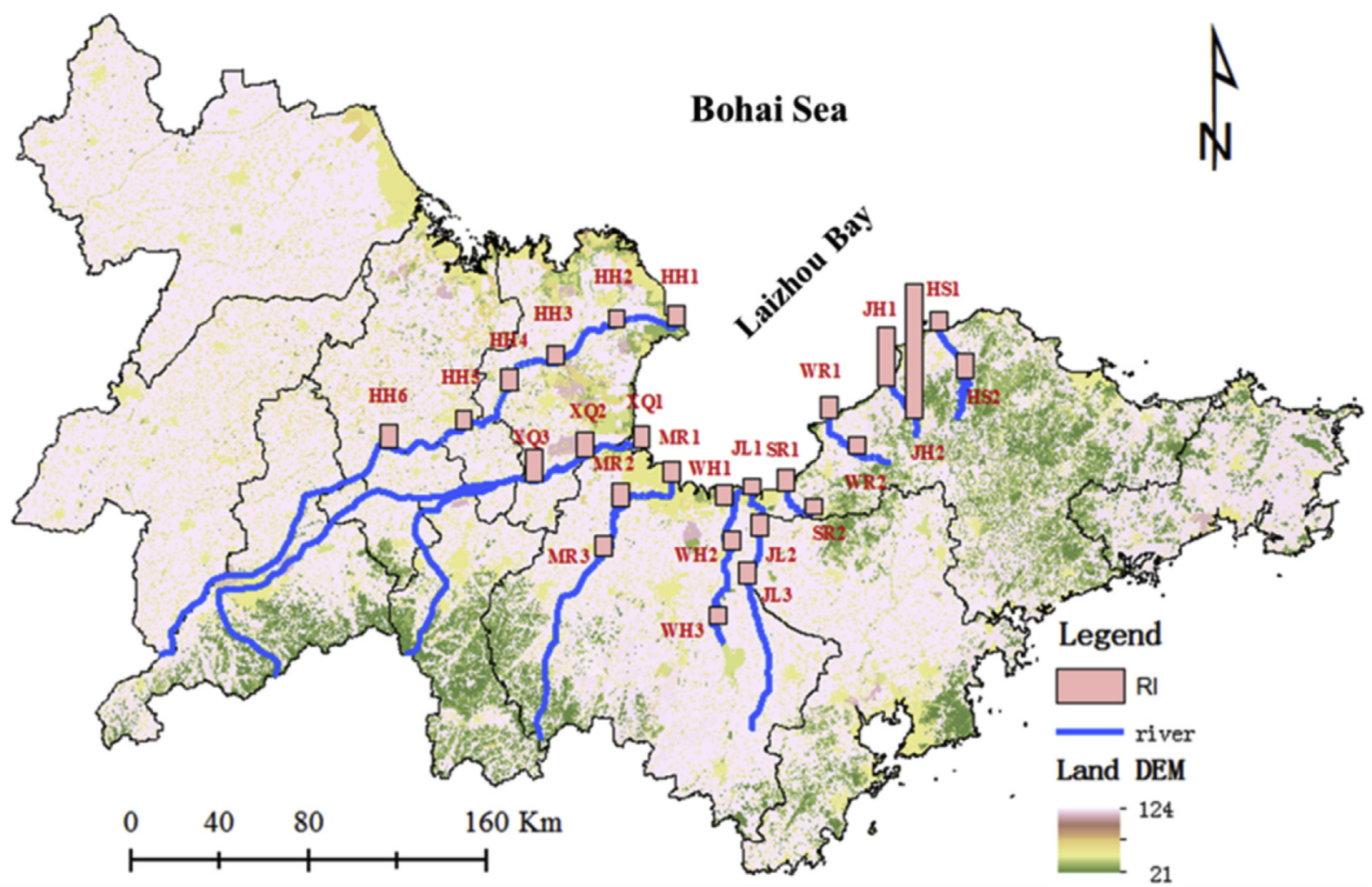

Fig. 4. The RI values of sediment from 9 rivers around watershed of Laizhou Bay. 
$\left(1008 \mathrm{~m}^{3} / \mathrm{s}\right)$. Although the average annual water discharge in Jie River was low $\left(1.17 \mathrm{~m}^{3} / \mathrm{s}\right)$, the total mass fluxes of six dissolved metals was still 101 tons per year, because of the high concentration of dissolved metal in Jie River.

The fluxes of dissolved metals in 9 rivers around the Laizhou Bay were also compared to those in rivers from other regions. The fluxes of six dissolved metals in Severnaya Dvina River were high than those in 9 coastal rivers around the Laizhou Bay, except for fluxes of $\mathrm{Cd}$ and $\mathrm{Pb}$ in Yellow river (Pokrovsky et al., 2010). The fluxes of dissolved $\mathrm{Ni}, \mathrm{Cu}, \mathrm{Zn}$ and $\mathrm{Cd}$ in St. Lawrence River were high than those in 9 coastal rivers around the Laizhou Bay (Yeats and Bewers, 1982). The fluxes of dissolved $\mathrm{Cu}$ and $\mathrm{Zn}$ in Odiel River and Tinto River were high than those in 9 coastal rivers (Olias et al., 2006). The fluxes of dissolved $\mathrm{Ni}$ and $\mathrm{Pb}$ in Odiel River and Tinto River were lower than those in Yellow Rivers, and the fluxes of dissolved $\mathrm{Ni}$ in Odiel River also lower than those in Xiaoqing River, Mi River, Wei River and Jiaolai River (Olias et al., 2006). The fluxes of dissolved $\mathrm{Cu}$ in Pearl River were just high than those in Sha River, Wang River and Huangshui River (Ye, 2001). The fluxes of dissolved $\mathrm{Cu}, \mathrm{Cd}$ and $\mathrm{Pb}$ in Min River were lower than those in Yellow Rivers, but lower than those in other rivers, except for $\mathrm{Cu}$ in Jie River (Lin et al., 1989). All in all, compared to rivers in other region, the mass fluxes of dissolved metals in river around Laizhou Bay were not high.

\subsection{Assessment of risks}

Concentration of dissolved $\mathrm{Cu}$ in the Jie River exceeded several drinking water criteria including WHO drinking water guidance value for $\mathrm{Cu}(2000 \mu \mathrm{g} / \mathrm{L})$, USEPA provisional health advisories for $\mathrm{Cu}$ $(1300 \mu \mathrm{g} / \mathrm{L})$, and the Chinese drinking water guidance value for $\mathrm{Cu}$ $(1000 \mu \mathrm{g} / \mathrm{L})$. Concentration of dissolved Cd in the Jie River exceeded several drinking water criteria including WHO drinking water guidance value for $\mathrm{Cd}(3 \mu \mathrm{g} / \mathrm{L})$, USEPA provisional health advisories for $\mathrm{Cd}(5 \mu \mathrm{g} / \mathrm{L})$, and the Chinese drinking water guidance value for $\mathrm{Cd}(5 \mu \mathrm{g} / \mathrm{L})$. Concentration of dissolved $\mathrm{Zn}$ and $\mathrm{Ni}$ in the Jie River exceeded the Chinese drinking water guidance value for $\mathrm{Zn}$ (1000 $\mu \mathrm{g} / \mathrm{L})$ and $\mathrm{Ni}(20 \mu \mathrm{g} / \mathrm{L})$, respectively. The residents in the catchment of Jie River have not used the river water as drinking water for a long time. However, the underground water might be contaminated by river surface water through surface-groundwater interactions (Li et al., 2014). So there is still a large potential risk to the local drinking water system. Meanwhile, river water is used for irrigation, which might pose risks due to heavy metals in soils and subsequent accumulation into crops and vegetables and eventually accumulation in humans.

The RI values of sediment from 9 rivers around Laizhou Bay were shown in Fig. 4. The RI value of one sediment sample (JH2) was higher than 600, which means very high ecological risk of metals, with the majority of pollution from $\mathrm{Cu}$ and $\mathrm{Cd}$. The RI value of one sediment sample (JH1) was higher than 300, which means considerable ecological risk from metals, with $\mathrm{Cu}$ and $\mathrm{Cd}$ being the two main contaminants. These two sediment samples were occurred at the Jie River. This result indicated that gold mining and smelting in the catchment of Jie Rivers has result in impressive ecological risk. The RI value of the majority of sampling sites (17/26) was higher than 150 , which indicate moderate ecological risk from metals. The RI values for the rest sampling sites were lower than 150, suggesting that these had low ecological risk from combined metal pollution. The RI value of sediment from 9 coastal rivers suggested that the government and relevant administrative department should pay more attention to the ecological risk of river ecosystem which flow to Laizhou Bay.

\section{Conclusion}

The present study is a part of an ongoing project to determine the concentration, speciation and environmental fate of metals in the Bohai Sea and Yellow Sea ecosystem. In the present study, the metal concentrations and speciation in water and sediments were determined, and the mass fluxes of dissolved metals in 9 coastal rivers were also estimated. The mean concentrations of $\mathrm{Cu}, \mathrm{Zn}, \mathrm{Cr}$, $\mathrm{Ni}, \mathrm{Cd}$ and $\mathrm{Pb}$ in sediments from 9 coastal rivers were $114,113,3.52$, $8.55,0.49$ and $1.51 \mu \mathrm{g} / \mathrm{L}, \mathrm{dw}$, respectively. The mean concentrations of $\mathrm{Cu}, \mathrm{Zn}, \mathrm{Cr}, \mathrm{Ni}, \mathrm{Cd}$ and $\mathrm{Pb}$ in sediments from 9 coastal rivers were $90.9,156,54.2,23.1,0.19$ and $25.1 \mathrm{mg} / \mathrm{kg}$, dw, respectively. Most of the $\mathrm{Cu}, \mathrm{Zn}, \mathrm{Cr}$, Ni and $\mathrm{Pb}$ in sediments from 9 rivers were preferentially bound to residual fraction. However, Cd was mainly associated with the exchangeable phase. The total mass fluxes of six dissolved metals in 9 coastal rivers were 869 tons per year. According to the RI values, the upstream of Jie River has very high ecological risk for the water body.

\section{Acknowledgments}

This study was supported by the Special Scientific Research Fund of Agricultural Public Welfare of China (Grant no. 20140301404) and the Innovation and Capacity-building Projects by the Beijing Academy of Agriculture and Forestry Sciences (project, KJCX20140302). We would like to thank the editors and reviewers for their valuable comments and suggestions.

\section{Appendix A. Supplementary data}

Supplementary data related to this article can be found at http:// dx.doi.org/10.1016/j.chemosphere.2017.01.046.

\section{References}

Akcay, H., Oguz, A., Karapire, C., 2003. Study of heavy metal pollution and speciation in Buyak Menderes and Gediz river sediments. Water. Res. 37, 813-822.

Chen, C.W., Kao, C.M., Chen, C.F., Dong, C.D., 2007. Distribution and accumulation of heavy metals in the sediments of Kaohsiung harbor, Taiwan. Chemosphere 66, 1431-1440.

Choi, K.Y., Kim, S.H., Hong, G.H., Chon, H.T., 2012. Distributions of heavy metals in the sediments of South Korean harbors. Environ. Geochem. Health 34, 71-82.

Cuong, D.T., Obbard, J.P., 2006. Metal speciation in coastal marine sediments from Singapore using a modified BCR-sequential extraction procedure. Appl. Geochem 21, 1335-1346.

Edinger, E.N., Azmy, K., Diegor, W., Siregar, P.R., 2008. Heavy metal contamination from gold mining recorded in Porites lobata skeletons, Buyat-Ratototok district, north Sulawesi, Indonesia. Mar. Pollut. Bull. 56, 1553-1569.

Farkas, A., Erratico, C., Vigano, L., 2007. Assessment of the environmental significance of heavy metal pollution in surficial sediments of the river Po. Chemosphere 68, 761-768.

Gao, X.L., Chen, C.T.A., 2012. Heavy metal pollution status in surface sediments of the coastal Bohai Bay. Water. Res. 46, 1901-1911.

Hakanson, L., 1980. An ecological risk index for aquatic pollution-control-a sedimentological approach. Water. Res. 14, 975-1001.

Hu, N.J., Shi, X.F., Liu, J.H., Huang, P., Yang, G., Liu, Y.G., 2011. Distributions and impacts of heavy metals in the surface sediments of the Laizhou Bay. Adv. Mar. Sci. 29, 63-72.

Huang, L.L., Pu, X.M., Pan, J.F., Wang, B., 2013. Heavy metal pollution status in surface sediments of Swan Lake lagoon and Rongcheng Bay in the northern Yellow Sea. Chemosphere 93, 1957-1964.

Huang, Y., Li, Y.X., Gao, P.W., Xu, M.M., Sun, B., Wang, N., Yang, J., 2015. Speciation and risk assessment of heavy metals in surface sediments from the heavily polluted area of Xiaoqing River. Environ. Sci. 36, 2046-2053.

Kadhum, S.A., Ishak, M.Y., Zulkifli, S.Z., Hashim, R.B., 2015. Evaluation of the status and distributions of heavy metal pollution in surface sediments of the Langat river basin in Selangor Malaysia. Mar. Pollut. Bull. 101, 391-396.

Li, J., Li, F.D., Liu, Q., Song, S., Zhao, G.S., 2013. Spatial distribution and sources of dissolved trace metals in surface water of the Wei River, China. Water. Sci. Technol. 67, 817-823.

Li, J., Li, F.D., Liu, Q., Zhang, Y., 2014. Trace metal in surface water and groundwater and its transfer in a Yellow River alluvial fan: evidence from isotopes and hydrochemistry. Sci. Total Environ. 472, 979-988.

Lin, F., Huang, J.H., Tang, Y.C., Xu, Q.H., 1989. The behavior of $\mathrm{Cd}, \mathrm{Pb}$ and $\mathrm{Cu}$ in the 
water of Min river. Acta Ocean. Sin. 11, 450-457.

Liu, F., Wang, H.T., Wang, D.L., 2004. Spatial distributions of heavy metals from the Laizhou Bay littoral wetland. Adv. Mar. Sci. 22, 486-492.

Liu, J.H., Song, J.J., Cao, L., Huang, W., Dou, S.Z., 2015. Spatial and temporal distribution, sources and ecological risk assessment of heavy metals in the surface sediments of Laizhou Bay. Asian J. Ecotoxicol. 10, 369-381.

Luo, X.X., Zhang, R., Yang, J.Q., Liu, R.H., Tang, W., Yan, Q., 2010. Distribution and pollution assessment of heavy metals in surface sediment in Laizhou Bay. Eco. Environ. Sci. 19, 262-269.

Maris, K., Agrita, B., Valery, R., Ilga, K., Elga, P., Inta, K., 2000. Heavy metals in rivers of Latvia. Sci. Total Environ. 262, 175-183.

Olias, M., Canovas, C.R., Nieto, J.M., Sarmiento, A.M., 2006. Evaluation of the dissolved contaminant load transported by the Tinto and Odiel rivers (South West Spain). Appl. Geochem 21, 1733-1749.

Osher, L.J., Leclerc, L., Wiersma, G.B., Hess, C.T., Guiseppe, V.E., 2006. Heavy metal contamination from historic mining in upland soil and estuarine sediments of Egypt Bay, Maine, USA. Estuar. Coast. Shelf 70, 169-179.

Pokrovsky, O.S., Viers, J., Shirokova, L.S., Shevchenko, V.P., Filipov, A.S., Dupre, B., 2010. Dissolved, suspended, and colloidal fluxes of organic carbon, major and trace elements in the Severnaya Dvina River and its tributary. Chem. Geol. 273, 136-149.

Qian, J.P., Chen, H.Y., Sun, T., Liu, C., Bai, Y.P., 2010. Study on geology and element geochemistry of Qiansunjia gold mine in Zhaoyuan, shandong, eastern China. Geochimica 39, 213-228.

Wang, P., Lu, Y.L., Wang, T.Y., Fu, Y.N., Zhu, Z.Y., Liu, S.J., Xie, S.W., Xiao, Y., Giesy, J.P., 2014. Occurrence and transport of 17 perfluoroalkyl acids in 12 coastal rivers in south Bohai coastal region of China with concentrated fluoropolymer facilities. Environ. Pollut. 190, 115-122.

Wang, T.Y., Wang, P., Meng, J., Liu, S.J., Lu, Y.L., Khim, J.S., Giesy, J.P., 2015. A review of sources, multimedia distribution and health risks of perfluoroalkyl acids (PFAAs) in China. Chemosphere 129, 87-99.

Wang, M.E., Chen, W.P., Peng, C., 2016. Risk assessment of Cd polluted paddy soils in the industrial and township areas in Hunan, Southern China. Chemosphere 144,
$346-351$

Xu, L., Lu, A.X., Wang, J.H., Ma, Z.H., Pan, L.G., Feng, X.Y., 2016. Effect of land use type on metals accumulation and risk assessment in soil in the peri-urban area of Beijing, China. Hum. Ecol. Risk. Assess. 22, 265-278.

Xu, L., Wang, T.Y., Ni, K., Liu, S.J., Wang, P., Xie, S.W., Meng, J., Zheng, X.Q., Lu, Y.L. 2013. Metals contamination along the watershed and estuarine areas of southern Bohai Sea, China. Mar. Pollut. Bull. 74, 453-463.

Xu, Y.D., Wei, X., Xia, B., Fu, X., Yue, Y.J., Wu, X.W., 2015. Potential ecological risk assessment of heavy metals in surface sediments of the eastern Laizhou Bay. Adv. Mar. Sci. 33, 520-528.

Yang, S.L., Zhou, D.Q., Yu, H.Y., Wei, R., Pan, B., 2013. Distribution and speciation of metals ( $\mathrm{Cu}, \mathrm{Zn}, \mathrm{Cd}$, and $\mathrm{Pb}$ ) in agricultural and non-agricultural soils near a stream upriver from the Pearl river, China. Environ. Pollut. 177, 64-70.

Yang, Z.F., Wang, Y., Shen, Z.Y., Niu, J.F., Tang, Z.W., 2009. Distribution and speciation of heavy metals in sediments from the mainstream, tributaries, and lakes of the Yangtze river catchment of Wuhan, China. J. Hazard. Mater 166, 1186-1194.

Ye, L.Q., 2001. Discussion on the flux of heavy meatals into the sea from the Pearl river. Environ. Exp. 16, 52-55.

Yeats, P.A., Bewers, J.M., 1982. Discharge of metals from the St. Lawrence river. Can. J. Earth Sci. 19, 982-992.

Yu, R.L., Hu, G.R., Wang, L.J., 2010. Speciation and ecological risk of heavy metals in intertidal sediments of Quanzhou Bay, China. Environ. Monit. Assess. 163 $241-252$.

Zheng, Y.M., Gao, M.S., Liu, S., Zhao, J.M., Guo, F., Wang, C.M., 2015. Distribution patterns and ecological assessment on heavy metals in the surface sediments of Laizhou Bay. Mar. Environ. Sci. 34, 354-360.

Zhuang, W., Gao, X.L., 2013. Acid-volatile sulfide and simultaneously extracted metals in surface sediments of the southwestern coastal Laizhou Bay, Bohai Sea: concentrations, spatial distributions and the indication of heavy metal pollution status. Mar. Pollut. Bull. 76, 128-138.

Zhu, Z.Y., Wang, T.Y., Wang, P., Lu, Y.L., Giesy, J.P., 2014. Perfluoroalkyl and polyfluoroalkyl substances in sediments from South Bohai coastal watersheds China. Mar. Pollut. Bull. 85, 619-627. 